\title{
TERRITÓRIOS NEGROS EM PORTO ALEGRE: TOPONÍMIA DA EMANCIPAÇÃO NEGRA NO MAPA DE 1888
}

Daniele Machado Vieira ${ }^{1}$

Resumo: Esse trabalho se insere no contexto de reconstituição dos antigos territórios negros em Porto Alegre/RS. Propõe trazer à tona a presença negra registrada no mapa de 1888, ano da Abolição da Escravidão, materializada em topônimos alusivos à emancipação negra. Campo da Redenção, Rua 28 de Setembro e Rua 13 de Maio inscrevem no espaço marcos do processo de emancipação, na escala local e nacional. Recorreu-se à análise histórico-geográfica para recuperar o espaço no tempo. A abordagem é amparada no contexto, ligando as denominações com o espaço geográfico que lhe dá suporte, conectando sua dimensão material (espaço físico) e simbólica (usos, sentidos, motivações). A cartografia rememora as antigas denominações dos espaços e sua ocupação pelo grupo negro. As toponímias fazem emergir os usos, as relações políticas e sociais envolvidas no seu batismo, e os significados dessas denominações para os negros.

Palavras-chave: territórios negros, toponímia, emancipação, cartografia, geografia histórica

\section{BLACK TERRITORIES IN PORTO ALEGRE/RS: TOPONYMY OF BLACK EMANCIPATION ON THE MAP OF 1888}

Abstract: This work is inserted in the context of reconstitution of the former black territories in Porto Alegre/RS. It proposes to bring out the black presence registered on the map of 1888 , year of the abolition of slavery, materialized in toponyms alluding to black emancipation. Redemption Field, September 28th Street and 13th May Street inscribe in the space milestones of the emancipation process, at the local and national scale. Historical-geographical analysis was used to recover space in time. The approach is sustained in the context, linking the denominations with the geographical space that supports them, connecting their material (physical space) and symbolic (uses, meanings, motivations) dimensions. Cartography recalls the former designations of spaces and their occupation by the black group. The toponymies bring out the uses, the political and social relations involved in their baptism, and the meanings of these denominations for blacks.

\footnotetext{
${ }^{1}$ Doutoranda, mestra e licenciada em Geografia pela Universidade Federal do Rio Grande do Sul (UFRGS). Professora na rede municipal de Porto Alegre/RS. E-mail: daniele vieira48@yahoo.com.br ; ORCID: https://orcid.org/0000-0003-0297-4071
} 

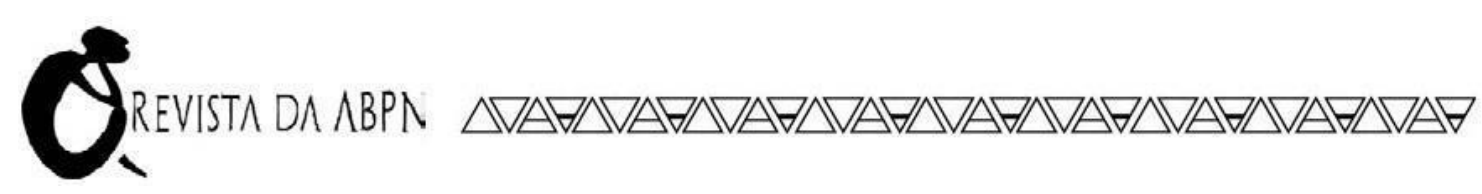

Keywords: black territories, toponymy, emancipation, cartography, historical geography.

\section{TERRITORIOS NEGROS EN PORTO ALEGRE: TOPONIMIA DE LA EMANCIPACIÓN NEGRA EN EL MAPA DE 1888}

Resumen: Este trabajo se inserta en el contexto de reconstitución de los antiguos territorios negros en Porto Alegre/RS. Propone dar énfasis a la presencia negra registrada en el mapa de 1888, año de la abolición de la esclavitud, materializada en topónimos referentes a la emancipación negra. El Campo de la Redención y las calles 28 de Septiembre y 13 de Mayo, inscriben en el espacio los marcos del proceso de emancipación en escala local y regional. A través del análisis histórico-geográfico, se busca recuperar el espacio en el tiempo. El planteamiento se apoya en el contexto, enlazando las denominaciones con el espacio geográfico que le soporta. Conectando su dimensión material (espacio físico) y simbólica (usos, sentidos, motivaciones). La cartografía rememora las antiguas denominaciones de los espacios y su ocupación por el grupo negro. Las toponimias provocan el surgimiento de los usos, las relaciones políticas y sociales involucradas en su bautismo, así como los significados de esas denominaciones para los negros.

Palabras-clave: territorios negros, toponimia, emancipación, cartografía, geografía histórica.

\section{TERRITOIRES NOIRS À PORTO ALEGRE/RS: TOPONYMIE D'ÉMANCIPATION NOIR DANS LA CARTE DE 1888}

Résumé: Ce travail s'insère dans le contexte de la reconstitution des anciens territoires noirs à Porto Alegre/RS. Il propose de mettre en évidence la présence noire enregistrée dans la carte de 1888, l'année de l'abolition de l'esclavage, matérialisé dans les toponymes allusives à l'émancipation noire. Champ de la rédemption, Rue 28 de Septembre et Rue 13 de Mai inscrivent dans l'espace les jalons du processus d'émancipation dans l'échelle locale et nationale. Nous avons choisi une analyse historico-géographique pour récupérer l'espace dans le temps. L'approche est soutenue dans le contexte, en connectant les dénominations avec l'espace géographique qui lui donne support, en connectant sa dimension matériel (espace physique) et symbolique (usages, sens, motivations). La cartographie remémore les anciennes dénominations des espaces et son occupation par le groupe noir. Les toponymes font émerger les usages, les relations politiques et sociaux impliquées dans son baptême, et les signifiés de ces dénominations par les noirs.

Mots-clés: territoires noirs, toponymie, émancipation, cartographie, géographie historique.

\section{INTRODUÇÃO}


Entre o final do século XIX e início do século XX constituíram-se na cidade de Porto Alegre/RS áreas que se caracterizaram pela presença negra, ficando conhecidos como antigos territórios negros. Entendemos territórios negros, enquanto espaços apropriados, marcados, qualificados, por grupos negros, ainda que não sejam exclusivos (RATTS, 2012, p. 232).

$\mathrm{Na}$ atualidade, diversos desses espaços quase não são lembrados como lugares outrora ocupados por grupos negros, como o Parque da Redenção - cartão postal e principal parque urbano da cidade. Observa-se um paulatino esquecimento desses espaços como representativos da presença negra.

Esse trabalho insere-se no contexto de reconstituição dos espaços outrora ocupados pela população negra na capital gaúcha, uma cidade que entre suas diversas faces também é negra. Embora, ao olhar externo, essa perspectiva raramente seja vista. As discussões aqui realizadas são parte da dissertação de mestrado da autora, intitulada Territórios Negros em Porto Alegre/RS (1800-1970): geografia histórica da presença negra no espaço urbano, a qual resultou na produção de uma cartografia dos antigos territórios negros sobre os mapas históricos da cidade.

Ao tratar das memórias das cidades, o geógrafo Mauricio de Almeida Abreu expõe que a busca pelo passado das cidades reflete a emergência da relação identitária entre os indivíduos e os conjuntos espaciais que lhes dão ancoragem no planeta, sendo esta uma busca por raízes (2014, p. 27). A memória da cidade diz respeito ao estoque de lembranças, eternizadas na paisagem ou nos registros de um determinado lugar, relacionadas a uma base material particular, um lugar específico, as quais são agora objeto de reapropriação por parte da sociedade (idem, p. 43). Tal memória citadina é composta por memórias coletivas, pertencentes a grupos diversos, sendo a memória coletiva entendida como o conjunto de lembranças construídas socialmente e referenciadas a um grupo que transcende o indivíduo (HALBWACHS, 2006).

Esse texto propõe trazer à tona a presença negra registrada no mapa de 1888, ano da Abolição da Escravidão, materializada em topônimos alusivos à emancipação negra. Inscritos no mapa histórico de 1888, o Campo da Redenção, a Rua 28 de Setembro e a Rua 13 de Maio são denominações que se referem a marcos do processo de emancipação negra na escala local e nacional, sendo aqui classificadas como toponímias da emancipação negra. 
As datas de 28 de setembro e 13 de maio são, respectivamente, as datas de assinatura da Lei do Ventre Livre e da Lei Áurea. O Campo da Redenção refere-se à libertação (parcial) dos escravizados na cidade de Porto Alegre em 1884, comemorado na época como abolição total. Esses marcos são entendidos como emancipacionistas por fazerem parte do processo de emancipação gradual, com ações que visavam uma libertação lenta, fragmentada, gradual (por isso diversas leis antecederam a Lei Áurea) e não a abolição imediata, irrestrita e definitiva de todos os escravizados, que só vai ocorrer no 13 de maio de 1888 (MOREIRA, 2003, p. 18).

Para reconstituir parte da memória destes espaços recorreu-se à análise históricogeográfica, a partir do cruzamento de fontes diversas: mapas históricos, crônicas, jornais, documentos históricos, tentando recuperar o espaço no tempo (ABREU, 2014, p. 45). Tal reconstituição extrapola o dado objetivo, dos topônimos inscritos no mapa, procurando relacioná-los com os processos sociais que lhes deram origem, visando atingir a densidade de significados relacionados a esses marcos emancipacionistas e sua apropriação pela população negra. Abreu contribui para essa visão, expondo que "o resgate da memória das cidades não pode se limitar à recuperação de formas materiais herdados de outros tempos. Há que se tentar dar conta também daquilo que não deixou marcas na paisagem [...]" (2014, p. 38). Assim, procura-se também perceber qual a relação dos grupos negros com essas as leis, como as interpretavam e quais usos faziam delas, buscando compreender os significados dessas denominações para esses indivíduos.

Voltando-nos para as denominações, o estudo dos nomes dos lugares é chamado de toponímia, bastante utilizado numa perspectiva etimológica. Jörn Seemann compreende a denominação dos lugares como um processo político-cultural, argumentando que as toponímias merecem uma análise mais detalhada que vá além dos nomes (topônimos) atribuídos às localidades (2005, p. 209). O autor propõe que o estudo das toponímias, numa perspectiva geográfica, siga algumas direções, as quais nos são úteis: i. pesquisa histórica contextualizada dos nomes dos lugares para revelar a dinâmica da sua denominação e renominação no tempo e no espaço; ii. correlação entre toponímia e mapa como legitimador da validade dos nomes; iii. interpretação do significado dos nomes dos lugares no processo de construir identidades em face ao simbolismo existente (SEEMANN, 2005). 
Concordamos com o autor de que os nomes dos lugares devem ser estudados inseridos no contexto do tempo e do espaço (SEEMANN, 2005, p. 209). A abordagem será amparada no contex to geográfico, ligando a denominação ao espaço geográfico que lhe dá suporte, conectando a dimensão material (espaço físico) à dimensão simbólica (usos, sentidos, motivações). O contexto histórico se voltará para as relações sociais e políticas da época, buscando os significados dos nomes, as motivações e os agentes envolvidos no batismo do local. Seemann destaca a necessidade da pesquisa histórica para compreender a dinâmica e o poder da toponímia, pois atrás dos nomes dos lugares existem pessoas ou grupos que os inventam, decretam, aceitam, rejeitam ou mudam (2005, p. 220).

Inscrever nomes de locais nos mapas, mais do que simples referência de localização, os torna oficiais, lhes conferindo legitimidade. O mapa não serve apenas para localizar, cumpre o papel de documento histórico atestando a presença negra na Porto Alegre antiga. A cartografia histórica revela, através dos topônimos, as marcas espaciais do grupo negro no espaço geográfico. Desde modo não só reconhece vozes historicamente silenciadas, como traz à tona marcas espaciais apagadas, "rugosidades" presentes num espaço "alisado" na construção de um território funcional e homogêneo (SANTOS, 2009, p. 14), implicando numa releitura do espaço urbano. A recuperação destes espaços propõe a construção de referenciais (materiais e simbólicos) positivos do segmento negro para a memória coletiva da cidade, com potencial de ressignificação das representações, muitas vezes restritas e depreciativas, sobre este grupo étnico-racial.

\section{A PORTO ALEGRE NEGRA - SÉCULO XIX}

Fundada em 1772, a cidade de Porto Alegre, capital do Rio Grande do Sul, tem registros de presença negra desde a sua formação. Em 1786, quando a população da cidade não passava de 1500 habitantes, cerca de 220 pessoas negras (livres e escravizadas) fundavam a Irmandade de Nossa Senhora do Rosário, importante instituição negra religiosa, que atravessou o século XIX, destacando-se no cenário religioso e social (MÜLLER, 2009, p. 264).

Ao longo do século XIX a presença negra é identificada em diversas faces da vida urbana, conformando territorialidades negras funcionais e religiosas. Os 
levantamentos populacionais revelam que em 1780 os pretos compunham cerca de 1/3 da população (PICCOLO, 1991, p. 41). Esse número cresce e em 1814 quase metade dos habitantes da cidade eram negros. Em 1858, esse grupo representa $30 \%$ do conjunto da população (idem).

Desenvolvendo uma vasta gama de ofícios (marinheiros, carregadores, alfaiates, babás, amas de leite, cozinheiros, padeiros, pintores, marceneiros, etc.) os negros destacavam-se no comércio de alimentos, ficando lembrados pelas "negras minas quitandeiras" que no mercado ou perambulando de um ponto a outro, abasteciam a cidade (PORTO ALEGRE, 1994, p. 100). Neste período os negros estavam concentrados na área central (núcleo urbano inicial) ou no seu entorno, conforme pode ser observado no Mapa das Territorialidades Negras em Porto Alegre - Século XIX (figura 3).

\section{MAPA HISTÓRICO DE 1888 - ANO DA ABOLIÇÃO}

Em 1888, ano da Abolição da Escravidão, a cidade recebe um novo mapa denominado "Planta de Porto Alegre Capital da Província do Rio Grande do Sul compreendendo os seus arraiais" elaborado por João Candido Jacques. O mapa apresenta dois quadros: o "Quadro das ruas e praças da cidade com os nomes que tiveram em outros tempos e os que tem atualmente" e outro denominado de "Quadro Estatístico", que consiste na legenda do mapa. No Quadro Estatístico estão identificados os equipamentos urbanos e prédios do governo: praças, hospitais, escolas, mercado, estação de bondes e trens, quartéis, cadeia, correios, teatro, trapiche e prédios do governo, numerados de 1 a 55 indicando a localização no mapa.

O quadro das ruas e praças da cidade está organizado em duas colunas, com o nome antigo e o atual ao lado. Grande parte das vias que tiveram seus nomes alterados eram os becos da área central, que não apenas ganham novas denominações, como são modificados quanto a hierarquia urbanística, deixando de ser "becos" e passando a ser ruas ou travessas. A maior parte desses logradouros tinham suas toponímias relacionadas a questões geográficas: ao relevo (Rua da Praia, Rua da Ladeira, Rua da Varzinha); às atividades desenvolvidas (Beco do Leite, Rua dos Sete Pecados) ou à funcionalidade (Praça do Portão). Grande parte das novas denominações homenageiam 
a Guerra do Paraguai (1864-1870), imortalizando nas ruas do Centro Histórico seus líderes (Duque de Caxias, General Osório), as batalhas (Riachuelo, Avahy), datas importantes da Guerra e os Voluntários da Pátria. Essas alterações já são indícios daquilo que Margaret Bakos classificou como "arrumando a sala de visitas", que consistiu numa série de medidas de cunho sanitário, moral, arquitetônico, e toda ordem de infraestrutura, que aspiravam a modernização da área central "a sala de visitas" na virada do século XIX para o XX (1994).

Até este momento os mapas tinham sua área restrita ao atual Centro Histórico, núcleo urbano principal, e seu entorno imediato, conforme pode ser observado no Mapa de 1868 (figura 3). O Mapa de 1888 é o primeiro mapa que mostra uma visão ampliada da cidade, incluindo também alguns arraiais e os caminhos de ligação com o interior e com a zona sul. Aparecem aí os arraiais do Menino Deus, Partenon (Bairro Santo Antônio), São Miguel (Bairro Santana), Navegantes e São Manoel (Bairro Moinhos de Vento), com algumas poucas ruas traçadas e ocupação incipiente. O Centro já está completamente adensado (inclusive com quadras projetadas na face norte), com o seu entorno imediato em franco processo de ocupação, conforme pode ser observado no Mapa Territórios Negros em Porto Alegre - 1888 (figura 1). Optamos por utilizar um recorte do mapa de 1888, com a área de estudo.

Esta também é a primeira vez que as áreas de dois dos antigos territórios negros aparecem no mapa: o Areal da Baronesa e a Colônia Africana. O polígono correspondente ao Areal da Baronesa já constava no mapa de 1881. Estes territórios negros formaram-se nas últimas décadas do século XIX, seguindo os eixos de expansão da cidade: o Areal da Baronesa ao sul e a Colônia Africana a leste. Na primeira década do século XX vão surgir, nas proximidades destes, outros dois territórios: a Ilhota, contígua ao Areal da Baronesa; e a Bacia do Mont'Serrat, a leste da Colônia Africana. Compreendidos como territórios negros, estes espaços se caracterizavam pela densidade de famílias negras residentes, pelas sociabilidades e práticas culturais desenvolvidas. São recorrentes e marcantes os relatos sobre a grande presença de casas de religião de matriz africana e a intensa atividade carnavalesca e festiva, em todos estes territórios.

Chama atenção que embora o mapa de 1888 inclua também os arraiais, os núcleos negros Areal da Baronesa e Colônia Africana não figuram como arraiais. Mesmo que estes espaços já estejam com urbanização semelhante aos demais arraiais: 
com algumas ruas abertas e nomeadas, ocupação incipiente. Outros documentos é que irão apontar esses espaços como núcleos negros, indicando sua área, sua ocupação e seus limites ao longo do tempo.

No mapa de 1888, o Areal da Baronesa aparece sem divisões ou ruas traçadas, somente com seus limites: Rua 28 de Setembro (sul), Rua 13 de Maio (leste), Arroio Dilúvio (nordeste), Rua de Bellas (futura Av. Praia de Belas) e o Lago Guaíba a oeste, Ponte de Pedra (norte). As construções estão concentradas na Rua 28 de Setembro, com vegetação ao fundo, indicando quintais para subsistência.

A Colônia Africana está em sua fase inicial, com apenas 5 ruas traçadas e pouquíssima ocupação. Esse antigo território negro irá se expandir, ocupando, aproximadamente, a área que na atualidade corresponde ao bairro Rio Branco, com registros que fazem menção a moradores negros na área até pelo menos a década de 1940.

Existem neste mapa várias toponímias relacionadas ao grupo negro, como as Ruas Castro Alves (conhecido como o poeta dos escravos) e Esperança, localizadas na Colônia Africana. Este trabalho centra-se nas toponímias referentes aos marcos da emancipação negra: i) na escala nacional: Rua 28 de Setembro (data da Lei do Ventre Livre) e Rua 13 de Maio (data da Abolição da Escravidão); ii) na escala local: Campo da Redenção - referente a libertação (parcial) dos escravizados em Porto Alegre. Chama atenção que mesmo o mapa sendo de 1888, nele já aparece a Rua 13 de Maio em alusão a Abolição ocorrida naquele ano. 
Figura 1: Mapa Territórios Negros em Porto Alegre - 1888

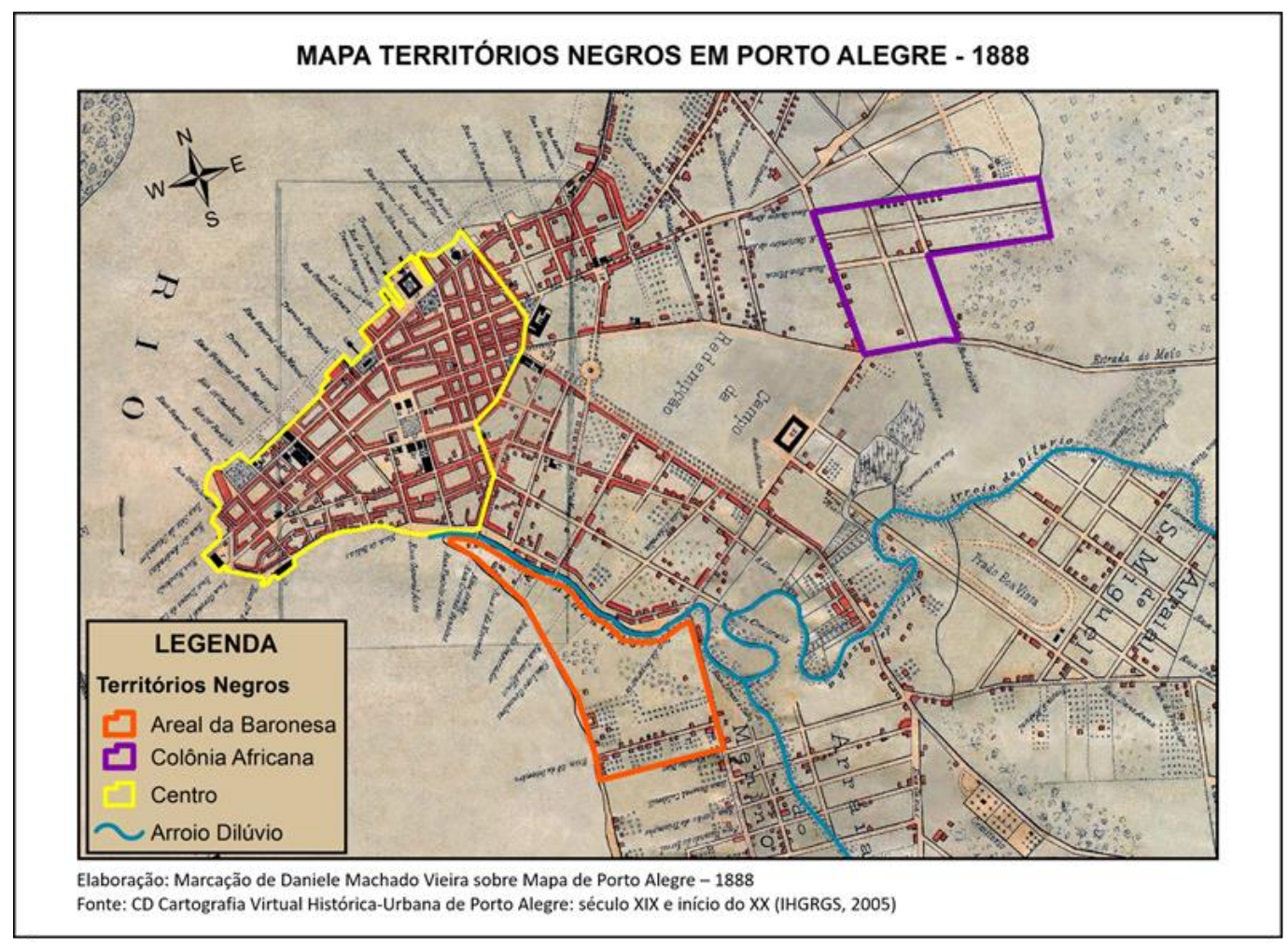

Fonte: Elaboração de Daniele Machado Vieira sobre o Mapa de Porto Alegre de 1888 (IHGRGS, 2005).

\section{RUA 28 DE SETEMBRO: ANTIGA RUA DOS PRETOS FORROS}

A Rua 28 de Setembro, limite sul do Areal da Baronesa, compreendia parte do que hoje conhecemos como Av. Ipiranga. Mais precisamente, o trecho localizado entre a Av. Praia de Belas (limite oeste da cidade à época) e a Rua 13 de Maio (atual Av. Getúlio Vargas), conforme destacado na figura 2. A data de 28 de setembro faz menção a Lei do Ventre Livre instituída em 28 de setembro de 1871, que passou a declarar livres os filhos de mulher escrava que nascessem a partir daquela data (BRASIL, 1871).

É emblemático que o limite sul do Areal da Baronesa, território negro, fosse um logradouro cuja denominação homenageava um marco da emancipação negra. A constatação da histórica presença negra neste espaço, através das toponímias, se torna mais evidente se levarmos em conta que a denominação anterior da Rua 28 de Setembro era Rua dos Pretos Forros. Considerando que forro referia-se aos negros libertos, a 
denominação costumeira da via "Pretos Forros" parece indicar o status de seus moradores (ROSA, 2014, p. 89).

Segundo Franco, a abertura da Rua dos Pretos Forros remete ao ano de 1870:

Já em 27/abr/1870, a Câmara ficou inteirada de que vários moradores de chácaras em terrenos comprados a Manoel Henrique da Silva Fróes haviam feito doação dos palmos faltantes para que fosse aberta no local uma rua com 80 palmos de largura, conforme as posturas municipais. Parece ter sido aí o nascimento da Rua dos Pretos Forros, que, na planta de 1888, já surge denominada como 28 de Setembro (FRANCO, 2006, p. 425).

Em 1874 a Rua dos Pretos Forros é citada como endereço de Rafael, homem pardo, de profissão carpinteiro, parte no processo crime $\mathrm{n}^{\circ} 1249$ (MATTOS, 2000, p. 47), confirmando a existência deste logradouro já na década de 1870.

No mapa de 1888 essa via já aparece nomeada como Rua 28 de Setembro e assim vai se conservar até a década de 1940, quando cede lugar à Av. Ipiranga e ao canal do Arroio Dilúvio, que começa a ser retificado. A Estatística Predial de 1892 aponta a existência de 46 casas térreas, 2 sobrados e assobradados neste logradouro, considerado populoso (FRANCO, 2006, p. 425). Essa elevada densidade populacional pode ser observada já no detalhe do mapa de 1888 (figura 2), no qual a Rua 28 de Setembro está repleta de construções, enquanto ruas do arraial vizinho, o Menino Deus, não apresentam ocupação semelhante.

Já no final do século, em agosto de 1897, uma notícia no jornal A Gazetinha faz menção a "Rua 28 de Setembro antiga Pretos Forros", indicando que a antiga denominação ainda era presente. Na ocasião, moradores da área relatam os problemas causados pela chuva, solicitando providências à intendência municipal, através do jornal. 
Figura 2: Mapa Toponímias - Ruas 28 de Setembro e 13 de Maio no Areal da Baronesa, Porto Alegre - 1888

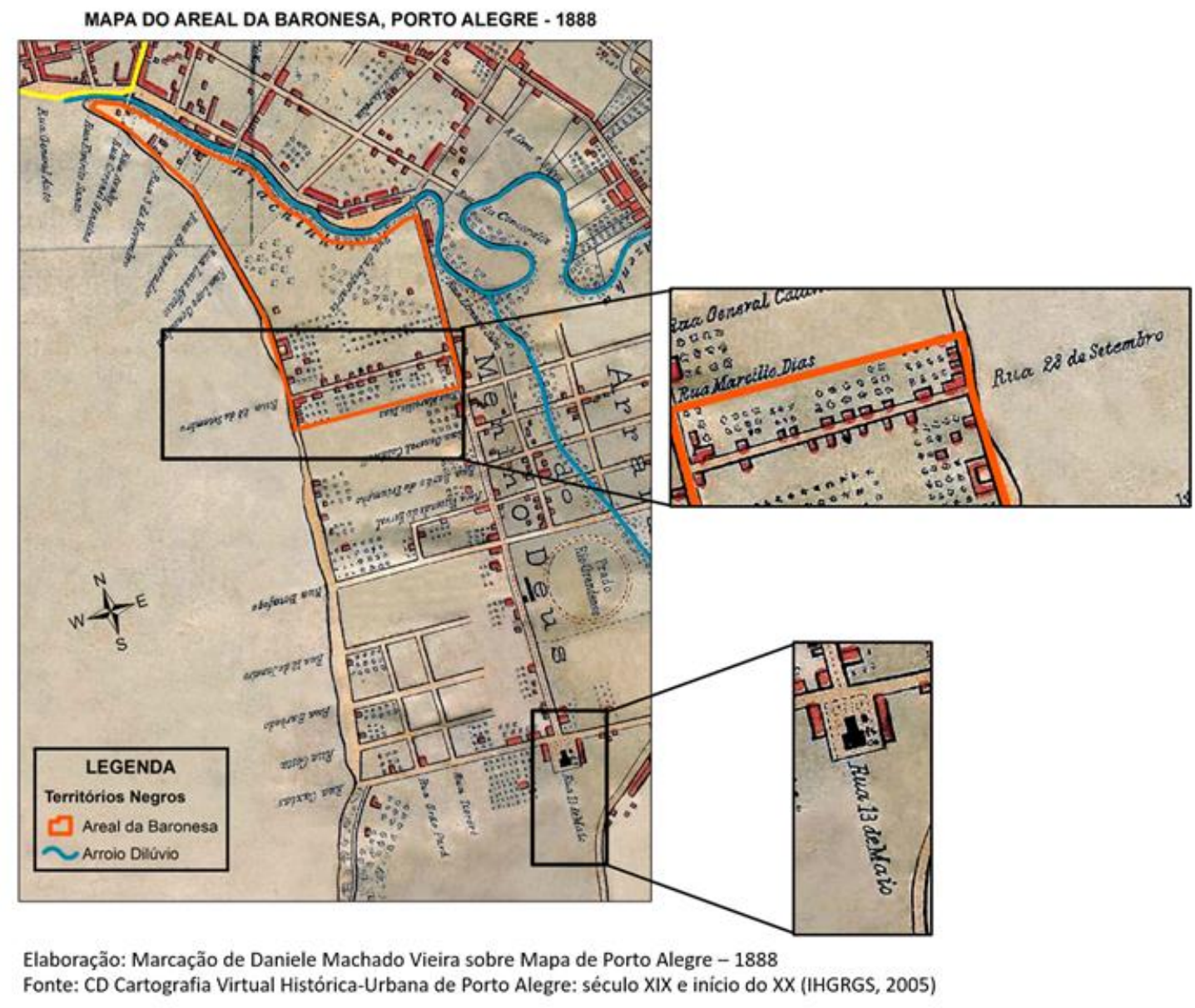

Fonte: Elaboração de Daniele Machado Vieira sobre o Mapa de Porto Alegre de 1888 (IHGRGS, 2005).

Amigo Sr. Redator. [...] chame a atenção do Sr. Intendente municipal para que ele verifique ou mande ver a Rua 28 de Setembro antiga Pretos Forros, no arraial do Menino Deus.

Com as últimas chuvas ficou aquela rua que é a mais transitada talvez, em um estado de horror (A GAZETINHA. Porto Alegre, 08/08/1897, AHPAMV).

A Rua dos Pretos Forros ficou imortalizada no poema de mesmo nome de Athos Damasceno Ferreira (1944, pp. 107-110), que traz o peso da escravidão na metáfora das "grossas, pesadas e rudes correntes", o temor das mulheres negras ao saberem que os filhos carregados em seus ventres virariam escravos. Aliás, é por isso que a lei se denomina "ventre livre", pois embora as mães permanecessem escravizadas, seus ventres gerariam filhos livres. Por fim o autor traz elementos da religiosidade e cultura 
negra como o batuque, o cucumbi (quicumbi), bem como instrumentos musicais que dão ritmo a tais manifestações: congos, ganzás, xequerês e agogôs.

\section{Rua dos Pretos Forros}

Não é o barulho das grossas, pesadas e rudes correntes que acorda o silêncio na boca da noite: - É O VENTO.

$[\ldots]$

As mães caminharam, chorando e escondendo no ventre os abortos que eram promessas de braços às eiras, aos campos e às tristes senzalas... $[\ldots]$

Aqueles, que um dia sofreram, encolhem o vulto, ajoelham na terra, e roçam a face no chão que regaram de suor e de pranto...

Há uma grande saudade chamando na luz das estrelas.

E rompe o batuque, começa o cucumbe, e as vozes procuram, envolvem o mundo perdido, ao bárbaro ruído soturno, dos congos, ganzás, xequerés e agogôs...

Como a Lei do Ventre Livre impactou na vida da população negra?

Ao instituir que todo filho nascido de mulher escrava seria livre, a Lei do Ventre Livre determinou que não nasceriam mais escravos no Brasil, pondo fim ao ciclo reprodutivo de mão-de-obra escravizada. É preciso considerar que nesta época o sistema escravista já estava em franco declínio, com a proibição desde 1850 da entrada de africanos escravizados no Brasil.

A lei 2040 de 1871 que ficou conhecida pelo seu artigo principal, ventre livre, estabeleceu também uma série de importantes regulamentações: i) para os escravizados: direito a formação de pecúlio (poupança, acúmulo de economias), autorização para firmarem contrato de prestação de serviços com terceiros para pagamento de sua alforria (por no máximo 7 anos), possibilidade de recorrer à justiça para serem libertos pelo preço de sua avaliação; ii) para os senhores: obrigatoriedade de matrícula dos seus escravizados; iii) para as províncias: constituição de fundo de emancipação (com prioridade de libertação para famílias escravizadas) (BRASIL, 1871). 
A formação de pecúlio, regulamentado pela Lei do Ventre Livre, foi o principal recurso utilizado pelos escravizados para a conquista da liberdade. Das 3427 alforrias levantadas pelo historiador Paulo Staudt Moreira (2003, p. 258), 41,1\% foram compradas, totalizando 1410 alforrias obtidas mediante pagamento aos senhores de escravos. A maior parte dessas alforrias (61\%) foram pagas com recursos próprios: $50 \%$ dos próprios escravizados e $11 \%$ de algum familiar, evidenciando a importância do pecúlio, o poder de acumulação dos escravizados e sua a disciplina para a poupança (idem, p. 259).

Entre as formas de obtenção dos recursos estão o trabalho aos domingos e dias santos (para terceiros ou por conta), ou por jornal (repassando uma parte ao senhor e ficando com uma parte) (MOREIRA, 2003, p. 260). Diversos desses trabalhadores escravizados tinham alguma especialização profissional - alfaiates, pedreiros, carpinteiro, lavradores, marceneiro - o que ampliava as chances de ganho através da prestação de serviços para terceiros nos seus dias livres.

A lei do Ventre Livre e suas diversas regulamentações foram amplamente utilizadas pela população negra na busca dos seus direitos. É o caso de Felicidade, mulher negra escravizada, de idade avançada, que em março de 1888 dirige-se pessoalmente ao inspetor da Alfândega para requerer a sua matrícula, servindo-lhe a inexistência do respectivo registro como carta de alforria (MOREIRA, 2003, p. 210). Felicidade conquistou a sua liberdade utilizando-se do Artigo $8^{\circ}$ da Lei 2040 de 1871, o qual determinava a obrigatoriedade da matrícula dos escravizados por parte dos senhores.

Art. $8^{\circ} \mathrm{O}$ Governo mandará proceder à matricula especial de todos os escravos existentes do Império, com declaração do nome, sexo, estado, aptidão para o trabalho e filiação de cada um, se for conhecida.

$\S 2^{\circ}$ Os escravos que, por culpa ou omissão dos interessados, não forem dados a matrícula, até um ano depois do encerramento desta, serão por este fato considerados libertos (BRASIL, 1871).

O 28 de setembro tornou-se uma data amplamente comemorada entre os negros da capital gaúcha, tamanha foi a importância da Lei do Ventre Livre para esse grupo. Considerando as possibilidades de conquista da liberdade trazidas pela lei, sua celebração tinha bons e concretos motivos. Em 1883 a data é celebrada com a entrega de 11 cartas de alforrias pela Sociedade Emancipadora Esperança e Caridade, composta 
por negros, durante festa no Teatro São Pedro, conforme noticiado pelo Jornal Mercantil (MOREIRA, 2003, p. 145).

Através das páginas do jornal negro O Exemplo, existente na cidade de Porto Alegre entre 1892 e 1930, conseguimos algumas pistas dos significados atribuídos aos marcos da emancipação negra e suas datas. O 28 de Setembro de 1904 serve como um momento de crítica à Independência, vista como incompleta pois a Pátria "mãe gentil" continuou a gerar filhos cativos (ZUBARAN, 2008, p. 174).

Já raiou a liberdade no horizonte do Brasil

Sendo ainda o ventre escravo da Pátria "mãe gentil"

Que ironia cruel! Que espanto sem igual!

Ouvia-se festivamente o Hino Nacional!

E a pátria ouvia assim as sínicas artimanhas

Sentindo o brasileiro escravo nas entranhas [...]

(O EXEMPLO, 09/10/1904, p. 2 apud ZUBARAN, 2008, p. 174)

Neste ano de 1904 também circulou nas páginas do jornal O Exemplo o convite para a comemoração da data na Sociedade Floresta Aurora, com a encenação da peça A Filha da Escrava "primorosa jóia literária da lavra do imortal escritor Arthur Rocha", dramaturgo negro do século XIX (O EXEMPLO, 28/09/1904, p. 2). Em 1909, o 28 de setembro foi saudado nas páginas do periódico como a "gloriosa data" que "veio suavizar as dores da mulher mãe, da infeliz escrava" que "via sair do seu ventre o seu amor querido preso aos elos da horrenda e repugnante cadeia - a escravidão" (O EXEMPLO, 28/09/1909, p. 1 apud ZUBARAN, 2008, p. 175).

A Lei 2040 de 28 de setembro de 1871 foi apropriada pela população negra escravizada nas suas ações em busca da liberdade, constituindo-se num marco significativo da passagem do cativeiro para a liberdade. No pós-abolição, a data seguiu repleta de significados compondo as comemorações de liberdade presentes nas páginas do jornal O Exemplo - a voz do homem de cor preta - e nos festejos da Sociedade Floresta Aurora, clube negro fundado em 1872 por negros forros, em atividade até a atualidade (ZUBARAN, 2008). 
O limite leste do Areal da Baronesa também remete a uma data significativa para a população negra: Rua 13 de Maio, data da Abolição da Escravidão negra no Brasil, instituída pela assinatura da Lei Áurea em 13/05/1888 (BRASIL, 1888).

A Rua 13 de Maio, em destaque no recorte do Mapa de 1888 (figura 2), recebe essa denominação em 1\%06/1888, já no mês seguinte a Abolição.

Como homenagem à abolição da escravatura, a resolução de 1\%06/1888 mudou o nome da Rua do Menino Deus para Rua 13 de Maio. Com essa denominação, a artéria conheceu talvez os seus melhores momentos em termos de importância. [...] Entre 1906 e 1909, fizera-se o calçamento da avenida e excelentes casas de moradia foram edificadas em toda a extensão da artéria, tornando-a uma das ruas mais nobres da cidade, durante um ciclo de trinta ou quarenta anos (FRANCO, 2006, p. 193).

Em 1935, numa homenagem ao presidente da época, a Rua 13 de Maio tem seu nome modificado para Av. Getúlio Vargas. Segundo Franco "em 24/11/1935, por ocasião da visita do Presidente Getúlio Vargas ao Estado, o Prefeito Alberto Bins baixou decreto, mudando o nome de 13 de Maio para Av. Getúlio Vargas, que até hoje conserva" (2006, p. 193). Essa mudança de nomenclatura apaga da memória urbana a relação da cidade com seus habitantes negros, apaga as marcas negras presentes no espaço urbano.

No período pós-abolição, o 13 de maio era uma data amplamente celebrada pela comunidade negra. Isso pode ser observado nos artigos "Emancipação dos escravos", "Salve 13 de maio!", "A magna data" e "13 de maio" alusivos à data, os quais circularam na primeira página do jornal O Exemplo no ano de 1910 (O EXEMPLO, 13/05/1910, p. 1). Na interpretação da historiadora Maria Angélica Zubaran "as comemorações do 28 de setembro e do 13 de maio foram utilizadas pelas lideranças negras para a reescrita e a reinvenção da história negra, para narrar e dar significado às memórias comuns da escravidão e da abolição" (2008, p. 170).

As ideias expressas por esses homens nas páginas do jornal O Exemplo, mostram como esses sujeitos apropriaram-se desses marcos históricos utilizando-os de modo celebratório, mas também crítico. Ao mesmo tempo em que saúdam o 13 de maio como a "luminosa data" fazendo menção ao sentido original - da libertação dos 
escravizados, incorporam um novo sentido: como um momento de reinvindicação da cidadania, que permitisse usufruir da liberdade de modo pleno.

No seu primeiro 13 de maio, em 1893, o jornal O Exemplo teve diversos artigos dedicados a data. Espiridião Calisto, redator do jornal, usa a data para denunciar a continuidade do preconceito na sociedade brasileira, qualificado por ele como "já não tão selvagem, porém mais aviltante", pois embora o cativeiro tenha sido destruído "sobreviveu o preconceito de raça, oficialmente instituído não em leis, mas impregnado nos costumes, o que é mais pernicioso". Finaliza destacando que "devemos festejar efusivamente a data luminosa de 13 de maio, como o início da reivindicação de nossos direitos de cidadãos brasileiros. Salve! 13 de Maio! (O EXEMPLO, 13/05/1893, p. 3).

Em outro artigo, Marcílio Freitas destaca o negro como protagonista da abolição, mostrando-se consciente da ativa e imprescindível participação negra no processo de libertação, descontruindo a narrativa da princesa Isabel como benfeitora:

[...] a nação brasileira hoje festeja uma de suas mais gloriosas datas - a da redenção dos cativos.

Foi uma das mais brilhantes conquistas da raça negra [...]

[...] Isabel, presumida redentora, então princesa regente, a qual por sua vez sancionou, não tanto por seus sentimentos humanitários, porém mais para cabal desempenho da abominável missão de que estava incumbida: a de cercar de prestígio as instituições já carcomidas, firmando assim seu trono (O EXEMPLO, 13/05/1893, p. 2)

Marcílio finaliza expondo que para sua honra "os negros compreenderam que nada tinham que agradecer, pois que apenas lhes tinham restituído o que de direito lhes pertencia" (idem). Esse pensamento rompe com um dos principais vínculos que se tentou criar durante o processo de emancipação: os laços de gratidão e fidelidade dos libertos, como parte de uma dívida moral com seus "benfeitores". Moreira relata que na passagem para o mundo dos livres, as atitudes senhoriais eram enaltecidas fazendo referência à benevolência, à ação nobre e generosa, aos sentimentos humanitários, "prendendo os libertos a laços de gratidão e obediência” para si e sua família (2003, p. 200).

Nas comemorações da Abolição de 1904, Espiridião Calisto evoca uma identidade negra afirmativa, orgulhosa da sua raça: "ser negro atualmente no Brasil é a mais nobre linhagem que se pode evocar, pois é ter-se a certeza que se descende de um povo herói do trabalho, mártir da ganância selvagem da ociosa raça dos descobridores 
deste pedaço da América” (O EXEMPLO, 13/05/1904, p. 1). Em outros momentos foram prestadas homenagens a homens considerados expoentes da raça negra, como uma forma de afirmação identitária, sendo comum menção a José do Patrocínio destacado como "a pena mais cintilante da imprensa brasileira" e a Luiz Gama, advogado abolicionista (O EXEMPLO, 13/05/1893, p. 3). No âmbito local é conferido destaque a Arthur Rocha, dramaturgo negro gaúcho, de breve vida (1859-1888), parte do distinto grupo de intelectuais negros livres do século XIX, o qual trazia em suas peças personagens negros cultos, bem-sucedidos e temas como a escravidão e a abolição (SANTOS, 2010).

Elevado ao panteão de homens negros ilustres, Arthur Rocha tinha suas peças "A Filha da Escrava" e "O Filho Bastardo" encenadas como parte das comemorações de liberdade nos salões da Sociedade Floresta Aurora. Em 13 de maio de 1904, o anuncio do evento convidava para um "espetáculo de gala, comemorativo da sublime data da libertação dos escravos no Brasil" com encenação do "esplendido drama" O Filho Bastardo "da lavra do inolvidável escritor riograndense Arthur Rocha" (O EXEMPLO, 13/05/1904, p. 4).

Os momentos de comemorações dessas datas emancipatórias também foram utilizados para marcar a consciência e a insatisfação negra com algumas questões: desde denúncias de preconceito, reivindicações de cidadania, críticas e até rompimento com a narrativa da princesa Isabel como figura benevolente e central da Abolição. Mas a luta e as reinvindicações negras em busca de seus direitos não foram inauguradas com o 13 de maio de 1888. Moreira relata que conforme se aproximava o fim da escravidão, aumentaram os casos de agressões realizadas por libertos contra pessoas que insistiam em tratá-los com desrespeito, principalmente em espaços públicos (2003, p. 293).

\section{CAMPO DA REDENÇÃO: PARA COMEMORAR A LIBERTAÇÃO DOS ESCRAVIZADOS}

A Várzea (ponto 7, Figura 3) era um grande terreno, baixo e alagadiço, contíguo ao núcleo urbano inicial (o Centro), local de passagem, caminho para o município de Viamão. Em 1881 ela passa a se chamar Campo do Bom Fim e em 1884 Campo da Redenção. Em 1888 é a primeira vez que a nomenclatura Campo da Redenção aparece 
num mapa (figura 1), embora a área já fosse retratada desde o primeiro mapa da cidade, de 1833.

Em 1884 a escravidão é dada como extinta na cidade de Porto Alegre, embora não tenha sido. Para comemorar a "redenção" dos escravizados e "solenizar de maneira perdurável o fato grandioso", os abolicionistas alteraram o nome da antiga Várzea para Campo da Redenção. A ata da "Sessão Extraordinária comemorativa da redempção dos escravos do município de Porto Alegre" realizada em 07/09/1884 na Câmara Municipal, registrou esse momento:

O sr presidente declarando que convocara a Câmara para comemorar a libertação dos escravos na cidade de Porto Alegre e seu município, propõe, para solenizar de uma maneira perdurável o fato grandioso e patriótico, que o Campo do Bom Fim passe a denominar-se "Campo da Redempção". É unanimemente aprovada esta proposta (CÂMARA MUNICIPAL DE PORTO ALEGRE, $07 / 09 / 1884$, p.2).

Esse evento compôs uma série de ações promovidas pelo Centro Abolicionista entre 1883 e 1884. Iniciando as suas atividades em 1883, o Centro Abolicionista vai em 1884 realizar uma fervorosa campanha abolicionista, percorrendo a cidade e logrando a libertação de quadras inteiras, com cartazes demarcando as "quadras libertas", numa verdadeira batalha simbólica (MOREIRA, 2003, pp. 172 - 173). Em 07/09/1884 foi comemorado o "fim" da escravidão em Porto Alegre culminando com a denominação do Campo da Redenção, como forma de marcar a "redenção da capital" no traçado urbano, eternizando esse acontecimento. É preciso lembrar que a Várzea não era um lugar de destaque como é o atual Parque da Redenção.

A narrativa sobre a Abolição construída pelo Centro Abolicionista foi classificada por Zubaran como "a invenção branca da liberdade negra" por omitir a participação dos negros no processo de emancipação, particularmente das sociedades negras Confraria de Nossa Senhora do Rosário, Sociedade Beneficente Cultural Floresta Aurora e Sociedade Emancipadora Esperança e Caridade (2009, pp. 3, 5). A Sociedade Emancipadora Esperança e Caridade contando majoritariamente com recursos oriundos das economias dos seus sócios-escravos logrou realizar 92 alforrias, mais que as sociedades não negras (MOREIRA, 2003, p. 131).

A participação de personagens negros importantes como o advogado abolicionista Soter Caio da Silva e o tenente-coronel Aurélio Viríssimo de Bittencourt, 
lembrado pelo jornal O Exemplo como "porta-voz dos primeiros ativistas que saudaram a aurora da emancipação", também foi minimizada (ZUBARAN, 2009, p. 5). Mas a liberdade, de modo amplo, teve como agente central pessoas comuns - os próprios escravizados, cujo esforço na acumulação do pecúlio foi destacado por Moreira como "o heroísmo de cada dia".

\begin{abstract}
As dificuldades inerentes à acumulação por parte dos escravos, tornava a tarefa de reunir o pecúlio um esforço que devia ocupar todas as horas livres daqueles trabalhadores. Jornadas de trabalho dobradas, ausência de dias de descanso (seja no domingo ou dias santos), cuidados especiais para não descuidar dos serviços de seus senhores (o que poderia prejudicar a dura negociação pela alforria) eram características dos seus cotidianos (2003, pp. 131-132).
\end{abstract}

O trabalho negro foi central em todo processo, pois as alforrias que não foram pagas com as economias dos cativos foram pagas em anos extras de serviços prestados, através das alforrias condicionadas à prestação de serviços. Na prática essa era uma estratégia de prolongamento da escravidão, permitindo aos senhores ainda usufruir do trabalho dos seus ex-escravos por um período de até 7 anos, como forma de indenização (ZUBARAN, 2009, p. 7).

Os levantamentos feitos por Moreira apontam que nas 3 últimas décadas da escravidão (1858-1888) a maioria das alforrias foram compradas (41\%), seguidas das alforrias condicionais (30\%) e com um percentual menor (18,9\%) as alforrias sem ônus ou condição (2003, p. 187). Apesar disso, a suposta "abolição" da escravidão de 1884 foi narrada como fruto da caridade dos "bondosos" proprietários de escravos, sem mencionar as muitas alforrias já realizadas (ZUBARAN, 2009, p. 11), atribuindo para si o protagonismo do processo de emancipação da capital.

Pesa sobre isso o fato de que em 1887 a cidade ainda registrava 58 escravizados, evidenciando que a escravidão ainda estava em vigor, contestando a "abolição" comemorada em 1884.

Depois de tantas comemorações e trocas de gentilezas entre os participantes da redenção da capital, foi com desgosto que, às 16 horas de 30 de março de 1887 , a matrícula de escravos de Porto Alegre fechou com um saldo positivo de 58 cativos - no qual não estavam, evidentemente, incluídos os contratados (MOREIRA, 2003, p. 180). 
No ano seguinte, meses antes da assinatura da Lei Áurea, uma proprietária ainda procurava por uma escravizada "que se inculcava forra", mediante anúncio no Jornal do Comércio em 10/01/1888:

Nas vésperas da abolição, uma senhora ainda reclamava de uma escrava fugida havia dois meses que se inculcava forra, e rogava "às pessoas que tenham conhecimento do lugar onde se acouta, o obséquio de se lhe avisarem" para acabar com as suas "trampolinices e vagabundagem" (apud MOREIRA, 2003, p. 49).

As evidências confirmam que, apesar das comemorações da "Redenção da Capital", a libertação definitiva dos escravizados em Porto Alegre só ocorreu de fato em 13/05/1888 com a promulgação da Lei Áurea que pôs fim a escravidão no Brasil de modo imediato e irrestrito. Ainda assim, há de se levar em conta que a denominação Redenção ao prestar homenagem à libertação, à redenção da população negra, constituise numa toponímia da emancipação negra.

Agora que já se conhece a origem do topônimo Campo da Redenção, outra questão que se coloca é o motivo da escolha daquele local para inscrever a libertação dos escravizados no espaço e na memória da cidade. Teria relação com a presença negra naquela área?

O cronista Coruja relata a existência, na primeira metade do século XIX, de um batuque intitulado Candombe da Mãe Rita, realizado na Várzea, localizado no ponto 4 das religiosidades no Mapa das Territorialidades Negras em Porto Alegre - Século XIX (figura 3$)^{2}$

O Candombe da Mãe Rita era na Várzea defronte da casa e curral do antigo matadouro, mais ou menos no terreno então baldio e depois ocupado pelas casas do Firmo e olaria do Juca [...].

Aí se reuniam nos domingos à tarde pretos de diversas nações, que com seus tambores, canzás, urucungus e marimbas, cantavam e dançavam esquecendo as mágoas da escravidão, sem que causassem maiores cuidados à polícia [...] (CORUJA, 1983, pp. 26-27).

Este batuque estaria localizado nas imediações da esquina da atual Rua Avaí com a Av. João Pessoa. O cronista Achylles Porto Alegre, outro importante memorialista do século XIX, colabora na localização informando que

\footnotetext{
2 As expressões candombe, candomblé e batuque fazem referência aos cultos religiosos de matriz africana. No Rio Grande do Sul o termo mais utilizado é batuque, candombe é bastante utilizado no Uruguai e candomblé em outras partes do Brasil.
} 
Rua Avaí: foi o beco do Firme ou rua do Valo. Alguns escrevem Firmo, mas é erro, porque recorda um nome - o de Antônio Francisco Firme. Tais terrenos, antes do arruamento e quando de todo abertos, serviam para a realização de festejos dos negros africanos, que ali realizavam seus ruidosos candomblés (PORTO ALEGRE, 1994, p. 16).

A designação da Várzea como local frequente para realização de batuques é confirmada pelo Código de Posturas Municipais, que em 1856 determina a proibição desses rituais na Várzea e em outros locais. O Art. 122 do capítulo $12^{\circ}$ estabelece que “ficam proibidos os candomblés ou batuques, e danças de pretos na Várzea, chácaras ou outro lugar. Pena $16 \$$ de multa ao dono da casa ou chefe de batuque e sendo escravo a 25 açoutes" (PICCOLO, 1991, p. 43).

Apesar dessa proibição, os batuques não cessaram completamente. Achylles Porto Alegre narra a realização de batuques em frente a Capelinha do Bom Fim, na Várzea, no último quartel do século XIX.

Havia também os "batuques" ao ar livre.

Nestes tomava parte quem queria, e creio que havia um "maioral" [...].

Um dos mais populares era o do Campo do Bom Fim, em frente à capelinha então em construção.

Cada domingo que Deus dava era certo um "batuque" ali, e o interessante é que muita gente se abalava da cidade para ir ver a dança dos negros (1994, p. 101).

O autor localiza esses batuques no espaço e no tempo. A Capelinha do Bom Fim está localizada na atual Av. Osvaldo Aranha (antigo Caminho do Meio), no lado oposto onde seria o Candombe da Mãe Rita (pontos 5 e 4 das religiosidades, figura 3). A capelinha esteve em construção entre 1867 e 1883, indicando a época de realização dos batuques citados por Achylles. Isso aponta que os batuques na Várzea prolongaram-se no tempo, aproximando-se de 1884, momento em que ela será denominada Campo da Redenção. É relevante também o fato de Achylles pontuar que "muita gente se abalava da cidade" para assistir os batuques, ratificando a informação de que a Várzea era considerada fora dos limites urbanos, conforme pode ser observado no Mapa de 1868 (figura 3).

Enquanto as crônicas de Coruja referem-se à primeira metade do século XIX, as de Achylles dizem respeito a segunda metade, evidenciando a existência de uma territorialidade negra batuqueira (e talvez outras) na Várzea ao longo de todo século 
XIX. A histórica relação do grupo negro com este espaço da cidade é tão marcante que o nome pelo qual continua a ser popularmente chamado - Parque da Redenção ou simplesmente Redenção - advém desta relação e resiste ao tempo.

Ainda que o batismo do "Campo da Redenção" possa soar como um autoelogio dos abolicionistas às suas realizações, "para solenizar de uma maneira perdurável o fato grandioso", por outro lado a ata de comemoração registrou que a denominação foi "para comemorar a libertação dos escravos da cidade”, evocando a histórica presença negra na área. A partir daí aquele espaço que já era conhecido pela frequente presença negra passou a ter seu nome vinculado ao grupo negro. Embora a nomenclatura oficial do parque tenha sido alterada para Parque Farroupilha em 1935 (nas comemorações do centenário Farroupilha), este espaço continua sendo chamado de Redenção, preservando simbolicamente a presença negra que ali conseguiu manter seus batuques. O Parque da Redenção é o principal parque urbano da cidade, cartão postal e ponto turístico.

Figura 3: Mapa das Territorialidades Negras em Porto Alegre/RS - Século XIX

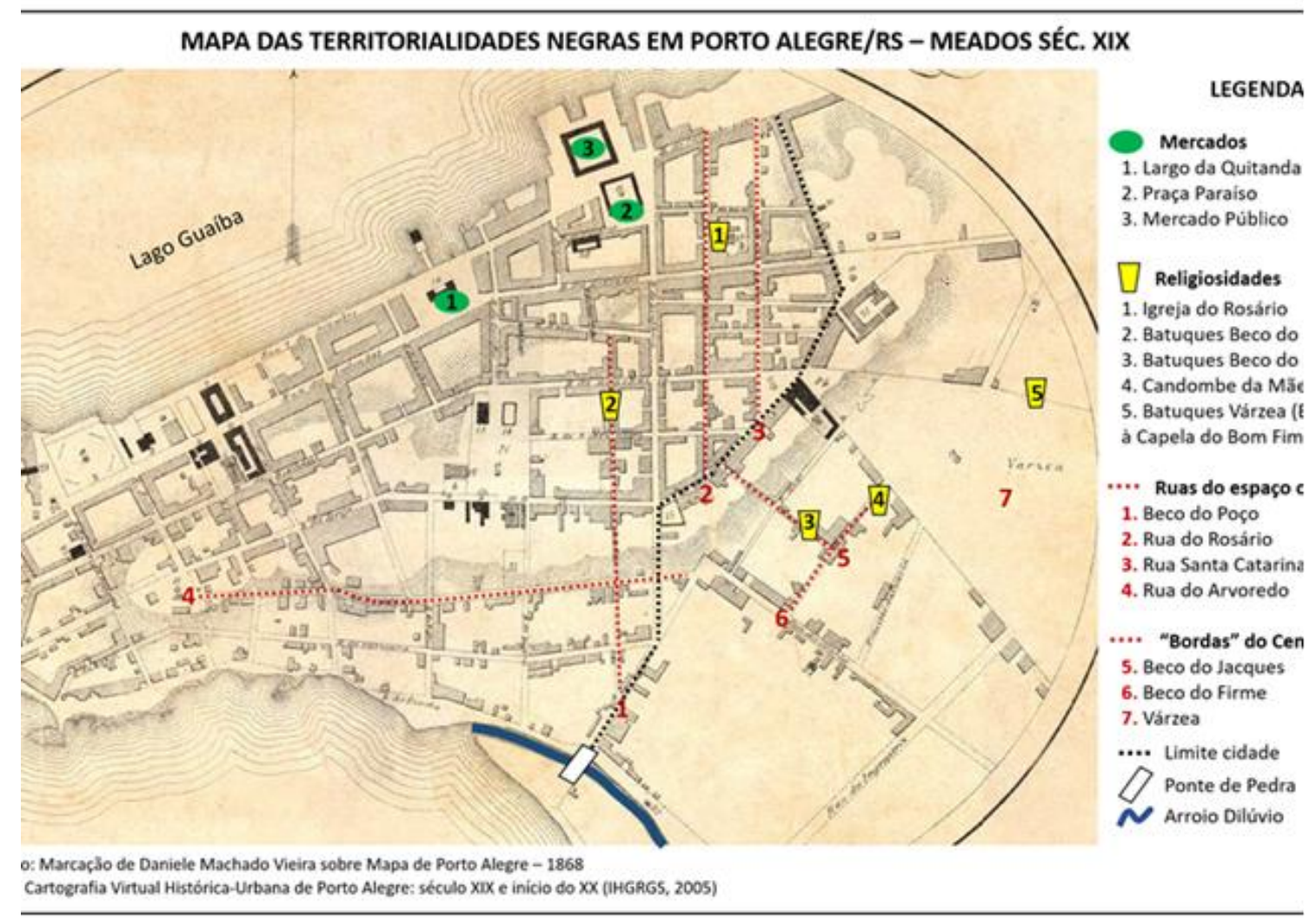

Fonte: Elaboração de Daniele Machado Vieira sobre o Mapa de Porto Alegre de 1868 (IHGRGS, 2005). 
Levando em conta as lutas cotidianas empreendidas pelos negros de Porto Alegre em busca da liberdade ao longo do século XIX, consideramos justa a apropriação da Redenção "para comemorar a libertação dos escravizados" como toponímia da emancipação negra dedicada àqueles que ocupavam aquele espaço e que foram os que de fato trabalharam para pagar suas alforrias, seja em dinheiro ou com prestação de serviços.

\section{CONSIDERAÇÕES FINAIS}

Através das toponímias alusivas à emancipação negra, inscritas no mapa histórico de 1888, pretendeu-se trazer à tona os espaços denominados por elas, tanto na sua dimensão física quanto simbólica.

A data de 28 de setembro, que passou a denominar a antiga Rua dos Pretos Forros, simbolizava um importante marco na passagem do cativeiro para liberdade, constituindo-se numa data repleta de significados para a população negra. Primeira das leis emancipacionistas, a Lei 2040 de 1871 determinou que não nasceriam mais escravos no Brasil, ao instituir que os ventres escravizados gerariam filhos livres. Além disso, as regulamentações presentes nos demais artigos constituíram possibilidades concretas de alcançar a liberdade, a exemplo do pecúlio, responsável pelo pagamento de $40 \%$ das alforrias nas últimas três décadas da escravidão. Os significados de liberdade relacionados a Lei do Ventre Livre mantiveram-se no pós-abolição, com o 28 de setembro sendo comemorado ainda nas primeiras décadas do século XX, tamanha foi a sua importância no processo de conquista da liberdade da população negra.

Além de denominarem, as toponímias também demarcam o uso daquele espaço. A Rua dos Pretos Forros faz menção a grande quantidade de negros libertos residentes naquele espaço. E simbolicamente tem sua denominação alterada para Rua 28 de Setembro, data da Lei do Ventre Livre, mantendo o sentido de liberdade negra vinculado àquele espaço.

A Rua 13 de Maio, limite leste do Areal da Baronesa, marca a data da Abolição da Escravidão no Brasil. As ideias que circularam nas páginas do jornal O Exemplo mostram que essa data continuou a ser amplamente celebrada no final do século XIX e nas primeiras décadas do Século XX. Esses momentos de comemorações da liberdade 
também foram utilizados de modo crítico, apontando os limites da Lei Áurea, que não acabou com o preconceito de cor, tampouco construiu condições para o pleno exercício da cidadania pelos negros. Ao significado original de liberdade, amplamente festejado, foram atribuídos novos sentidos e outras narrativas, inclusive posicionando os negros como agentes centrais na conquista da liberdade, rompendo com a narrativa da princesa Isabel como redentora.

A denominação Campo da Redenção refere-se ao processo de emancipação negra à escala local, sendo escolhida para marcar o processo de libertação, de "redenção" dos negros da cidade, que teria ocorrido em 1884. Apesar deste não ter sido o fim da escravidão na cidade, o topônimo Redenção vincula a denominação referente a libertação negra a um espaço ocupado pelo grupo e seus batuques ao longo do século XIX, conectando materialidade (denominação, espaço físico) e imaterialidade (seus antigos usos e significados). Na contemporaneidade, essa denominação, mais de 130 anos depois do batismo do atual Parque da Redenção, rememora questões importantes para a memória coletiva da cidade: i) os usos do espaço: os batuques negros; ii) a paisagem e o contexto urbano da cidade no final do século XIX e iii) o processo emancipacionista da capital e seu contexto.

Se por um lado o topônimo Campo da Redenção foi atribuído pelos abolicionistas, agentes hegemônicos, que talvez tivessem interessados em marcar seus nobres feitos na história. Por outro lado, esse topônimo é alusivo à libertação negra, evocando os negros que não só ocupavam aquele espaço como também foram agentes centrais no processo de emancipação, constituindo-se numa toponímia da emancipação negra.

Ao mesmo tempo que as toponímias se referem a processos sociais relacionados a emancipação da população negra, elas demarcam espaços ocupados por esse grupo. Para além do topônimo, do nome do lugar em si, buscou-se o que os nomes dos lugares podiam revelar, sendo possível alcançar a antiga ocupação e os usos do espaço, os significados que tais denominações tinham para o grupo negro, os motivos e os agentes envolvidos no batismo.

A mudança de nomenclatura nas décadas de 1930/40 apagou a presença negra desses logradouros, apagando marcas negras do espaço urbano. O desaparecimento de algumas destas toponímias implica em grande prejuízo, pois enfraquece a memória da 
relação destes espaços com a população negra. Trazer esses registros ultrapassa a questão relativa a coletividade negra, diz respeito a memória da cidade, importante para todos os seus cidadãos.

A cartografia rememora as antigas denominações, atualizando a memória dos espaços antigamente ocupados pelo grupo negro. Ao mesmo tempo cumpre a função de documento histórico atestando a presença negra nos logradouros da cidade.

\section{REFERÊNCIAS BIBLIOGRÁFICAS}

ABREU, Mauricio de Almeida. Sobre a memória daBs cidades. In: FRIDMAN, Fania e HAESBAERT, Rogério (Orgs). Escritos sobre espaço e história. Rio de Janeiro: Garamond, 2014. p. 27-54.

A GAZETINHA. Porto Alegre, 08/08/1897, Arquivo Histórico de Porto Alegre Moysés Vellinho.

BAKOS, Margaret Marchiori. Decorando a sala de visitas: Porto Alegre na virada do século XIX. In: MAUCH, Claudia (Org.). Porto Alegre na virada do século 19: cultura e sociedade. Porto Alegre, Canoas, São Leopoldo: Ed. UFRGS, Ed. ULBRA, Ed. UNISINOS, 1994. p. 144154.

BRASIL. Lei 2040, de 28 de setembro de 1871. Lei do Ventre Livre. Disponível em: http://www.planalto.gov.br/ccivil_03/leis/lim/lim2040.htm. Acesso em: 02/03/2020.

BRASIL. Lei 3353, de 13 de maio de 1888. Lei Áurea. Disponível em: http://www.planalto.gov.br/ccivil_03/leis/lim/LIM3353.htm. Acesso em: 02/03/2020.

BRASIL. Ministério da Educação. Diretrizes Curriculares Nacionais para a Educação das Relações Étnico-Raciais e para o Ensino de História e Cultura Afro-Brasileira e Africana. Brasília, 2004. Disponível em: <http://www.uel.br/projetos/leafro/pages/arquivos/DCN-s\%20\%20Educacao\%20das\%20Relacoes\%20Etnico-Raciais.pdf> . Acesso em: 02/09/2018

CÂMARA MUNICIPAL DE PORTO ALEGRE. Ata da Sessão Extraordinária comemorativa da redempção dos escravos do município de Porto Alegre, realizada no dia 07/09/1884. Livro de Ouro, p. 2 e 3.

CORUJA, Antônio Alvares Pereira. Antigualhas: reminiscências de Porto Alegre. Porto Alegre: Cia União de Seguros Gerais, 1983.

FERREIRA, Athos Damasceno. Poemas da minha cidade. $2^{\mathrm{a}}$ Ed. Porto Alegre: Livraria do Globo, 1944.

FRANCO, Sérgio da Costa. Porto Alegre: guia histórico. $4^{\text {a }}$ ed. (1 ${ }^{\text {a }}$ ed. 1988). Porto Alegre: Ed. UFRGS, 2006.

HALBWACHS, Maurice. A memória coletiva. 2 ed. São Paulo: Centauro, 2006. 
IHGRGS. Cartografia Virtual Histórica-Urbana de Porto Alegre: século XIX e início do XX. Porto Alegre: Instituto Histórico e Geográfico do Rio Grande do Sul, 2005. CD.

MATTOS, Jane Rocha de. Que arraial que nada, aquilo lá é um areal: O Areal da Baronesa: imaginário e história (1879-1921). 158 f. Dissertação (Mestrado em História do Brasil) Programa de Pós-graduação em História, Faculdade de Filosofia e Ciências Humanas, Pontifícia Universidade Católica do Rio Grande do Sul, Porto Alegre, RS, 2000.

MOREIRA, Paulo Roberto Staudt. Os cativos e os homens de bem: experiências negras no espaço urbano, Porto Alegre 1858-1888. Porto Alegre: EST Edições, 2003.

MÜLLER, Liane Susan. As contas do meu rosário são balas de artilharia. In: SILVA, Gilberto Ferreira da; SANTOS, José Antônio dos; CARNEIRO, Luiz Carlos da Cunha (Orgs.). RS NEGRO: cartografias sobre a produção do conhecimento. Porto Alegre: EDIPUCRS, 2009. p. 262-271. Disponível em: http://www.pucrs.br/edipucrs/ahrs/rsnegro.pdf. Acesso em: $23 / 01 / 2017$.

O EXEMPLO, Porto Alegre, 13/05/1893, 13/05/1904, 28/09/1904, 13/05/1910. Disponível em: Acervo on-line coleções jornal "O Exemplo" - http://afro.culturadigital.br/. Acesso em: $15 / 03 / 2017$

PICCOLO, Helga Iracema Landgraf. Porto Alegre - meados do século XIX: a cidade negra. In: Reunião Sociedade Brasileira de Pesquisa Histórica, 10, 1990, Curitiba. Anais X Reunião Sociedade Brasileira de Pesquisa Histórica. Curitiba: SBPH, 1991. p. 41-47.

PORTO ALEGRE, Achylles. História popular de Porto Alegre. Porto Alegre: PMPA Unidade Editorial, 1994.

RATTS, Alex. Os lugares de gente negra: temas geográficos no pensamento de Beatriz Nascimento e Lélia Gonzalez. In: SANTOS, Renato Emerson dos (Org.). Questões Urbanas e Racismo. Petrópolis, Brasília: DP et. Alii.; ABPN, 2012. p. 216-243.

ROSA, Marcus Vinícius de Freitas. Além da invisibilidade: história social do racismo em Porto Alegre durante o pós-abolição (1884-1918). 332 f. Tese (Doutorado em História) - Programa de Pós-graduação em História, Instituto de Filosofia e Ciências Humanas, Universidade Estadual de Campinas, Campinas, SP, 2014.

SANTOS, Isabel Silveira dos. Arthur Rocha: um intelectual negro no "mundo dos brancos". In: ENCONTRO ESTADUAL DE HISTÓRIA, X, Santa Maria. Anais X Encontro Estadual de História. Santa Maria: UFSM, 2010, p. 1-16. Disponível em: http://www.eeh2010.anpuhrs.org.br/resources/anais/9/1279496410_ARQUIVO_arthurrochaumintelectualnegronomundodo sbrancos.pdf. Acesso em: 10/02/2020

SANTOS, Renato Emerson dos. O ensino de Geografia do Brasil e as relações raciais: reflexões a partir da Lei 10.639. In: SANTOS, Renato Emerson dos (Org.). Diversidade, espaço e relações étnico-raciais: o negro na Geografia do Brasil. Belo Horizonte: Gutenberg, 2009. p. 21-40.

SEEMANN, Jörn. Toponímias como construção histórico-cultural: o exemplo dos municípios do estado do Ceará. Vivência, Natal, n. 29, 2005, p. 207-224.

VIEIRA, Daniele Machado. Territórios Negros em Porto Alegre/RS (1800-1970): geografia histórica da presença negra no espaço urbano. 189 f. Dissertação (Mestrado em Geografia) - 
Programa de Pós-graduação em Geografia, Instituto de Geociências, Universidade Federal do Rio Grande do Sul, Porto Alegre, RS, 2017.

ZUBARAN, Maria Angélica. Comemorações da liberdade: lugares de memórias negras diaspóricas. Anos 90, Porto Alegre, v. 15, n. 27, p. 161-187, jul. 2008. Disponível em: http://www.seer.ufrgs.br/anos90/article/viewFile/6743/4045. Acesso em: 06/02/2017.

ZUBARAN, Maria Angélica. A invenção branca da liberdade negra: memória social da abolição em Porto Alegre. Revista de História e Estudos Culturais, Uberlândia, v. 6, n. 3, p. 116, jul.ago.set 2009. Disponível em:

http://www.revistafenix.pro.br/PDF20/ARTIGO_3_DOSSIE_Maria_Angelica_Zubaran_FENIX _JULAGO_SET_2009.pdf . Acesso em: 06/02/2017.

Recebido em: $22 / 09 / 2020$

Aceito em: 30/10/2020 